\title{
DETERMINAN TINGKAT PENGETAHUAN IBU HAMIL TENTANG PEMERIKSAAN TRIPLE ELIMINASI
}

\author{
Bintang Petralina ${ }^{1}$ \\ 1Prodi D3 Kebidanan, Universitas Binawan, Jl. Dewi Sartika Cawang, \\ Kramatjati, Jakarta Timur, 13630 \\ petralina@binawan.ac.id
}

\begin{abstract}
Background : The 2016 Indonesian Demographic Health Survey said that the Maternal Mortality Rate (MMR) in Indonesia has reached 235 per 100,000 live births. The global target of SDG's (Sustainable Development Goals) is to reduce the MMR to 70 per 100,000 live births. Referring to the current conditions, the potential to achieve the SDG's target to reduce MMR requires earnest hard work. Health data shows there is $0.3 \%$ risk of HIV transmission in pregnant women, $1.7 \%$ syphilis infection in pregnant women, and $2.5 \%$ hepatitis infection in pregnant women.

Purpose : This study aims to identify the triple elimination examination in pregnant women in terms of the knowledge of pregnant women at PMB Suciati.

Research Methods : The type of this research is analytic descriptive with research sites in PMB Suciati, M.Kes with the research subjects of all pregnant women who visited in March 2019 as many as 40 pregnant women. The research methods used for sampling is accidental sampling, for data collection using questionnaires, and to analyse data using computer software.

Results : The results showed that the level of knowledge of pregnant women about triple elimination examinations was low at 33 (82\% of respondents), $15 \%$ (6 respondents) had sufficient knowledge, and $3 \%$ (1) of respondents had a good level of knowledge.

Conclusion : The triple elimination examination in pregnant women in terms of knowledge in the BPM Suciati is majority still low (82\%).
\end{abstract}

Keywords: triple elimination, pregnant women

\begin{abstract}
Abstrak
Permasalahan :Survey Demografi Kesehatan Indonesia (SDKI) tahun 2016 mengatakan bahwa Angka Kematian Ibu (AKI) di Indonesia mencapai 235 per 100.000 kelahiran hidup. Target global SDG's (Suitanable Development Goals) adalah menurunkan AKI menjadi 70 per $100.000 \mathrm{KH}$. Mengacu pada kondisi saat ini, potensi untuk mencapai target SDG's untuk menurunkan AKI diperlukan kerja keras dan sungguh-sungguh untuk mencapainya. Data kesehatan menunjukkan risiko penularan HIV pada ibu hamil $0,3 \%$, infeksi Sifilis pada ibu hamil 1,7\%, dan infeksi Hepatitis pada ibu hamil $2,5 \%$.

Tujuan Penelitian : Penelitian ini bertujuan untuk mengetahui tentang pemeriksaan triple eliminasi pada ibu hamil ditinjau dari aspek pengetahuan ibu hamil di PMB Suciati.

Metode Penelitian : Jenis penelitian ini adalah deskriptif analitik dengan lokasi penelitian di PMB Suciati,M.Kes dengan subyek penelitian semua ibu hamil yang berkunjung pada bulan maretmei 2019 sebanyak 40 ibu hamil. Pengambilan sampel menggunakan acidental sampling, pengumpulan data menggunakan kuestioner dan analisa data menggunakn software computer. Hasil : Hasil penelitian menunjukkan bahwa tingkat pengetahuan ibu hamil tentang pemeriksaan triple eliminasi rendah sebanyak $82 \%$ (33 responden), 6 responden $15 \%$ (6 responden) mempunyai pengetahuan cukup dan $3 \%$ (1 responden) responden mempunyai tingkat pengetahuan baik.

Kesimpulan :Pemeriksaan triple eliminasi pada ibu hamil ditinjau dari aspek pengetahuan di BPM Suciati mayoritas masih rendah (82\%).
\end{abstract}

Kata kunci : triple eliminasi, ibu hamil 


\section{PENDAHULUAN}

Kesehatan merupakan salah satu simbol kesejahteraan suatu bangsa. Tolok ukur keberhasilan dalam kesejahteraan adalah angka morbiditas dan mortalitas baik pada ibu maupun anak, yang tentunya memerlukan berbagai upaya seperti: promotif, preventif, kuratif dan rehabilitatif. Angka Kematian Ibu (AKI) merupakan salah satu indicator dalam menentukan derajat kesehatan masyarakat. Di Indonesia angka kematian ibu merupakan angka tertinggi dibandingkan negara-negara ASEAN lainnya.

Survey demografi kesehatan Indonesia (SDKI) tahun 2016 mengatakan bahwa angka kematian ibu di Indonesia mencapai 235 per 100.000 kelahiran hidup. Target global SDGs (Suitanable Development Goals) adalah menurunkan Angka Kematian Ibu (AKI) menjadi 70 per $100.000 \mathrm{KH}$. Mengacu dari kondisi saat ini, potensi untuk mencapai target SDGs untuk menurunkan AKI adalah off track, artinya diperlukan kerja keras dan sungguh-sungguh untuk mencapainya. AKB di Provinsi DKI Jakarta menurut data seksi kesehatan keluarga Dinkes DKI Jakarta tahun 2016 sebesar 3 bayi mati per $1000 \mathrm{KH}$. Jakarta Barat memiliki jumlah kematian bayi terbanyak pada tahun 2015, yaitu jumlah 219 bayi mati.Wilayah dengan jumlah kasus kematian bayi terendah adalah kabupaten kepulauan seribu dengan jumlah kematian bayi sebanyak 3 bayi (Profil Kesehatan DKI Jakarta, 2016).

Profil kesehatan provinsi DKI Jakarta pada tahun 2016 jumlah Kematian Ibu yaitu 97 kalahiran hidup $(\mathrm{KH})$, yang mana AKI tertinggi tertinggi pertama yaitu di Jakarta Timur $34 \mathrm{KH}$. Tertinggi ke dua yaitu di Jakarta Utara dengan $23 \mathrm{KH}$, Jakarta Barat $16 \mathrm{KH}$, Jakarta Pusat $12 \mathrm{KH}$, Jakarta Selatan $12 \mathrm{KH}$, sedangkan di kepulauan seribu tidak ada kejadian kematian ibu. Adapun penyebab kematian langsung ibu adalah perdarahan sebesar $28 \%$ infeksi sebesar $11 \%$ eklampsia sebesar $24 \% \quad$ Kemungkinan terjadinya kematian ibu dalam persalinan di puskesmas atau kerumah sakit karena kesiapan petugas, ketersediaan bahan, peralatan dan sikap petugas. Di perjalanan diakibatkan sarana transportasi, tingkat kesulitan dan waktu tempuh, serta kematian di rumah diakibatkan keputusan keluarga (pengetahuan, ketersediaan dana, kesibukan keluarga dan social budaya).

Kematian ibu karena infeksi disebabkan beberapa faktor, salah satunya infeksi pada alat reproduksi dan penyakit menular seksual seperti HIV, Sifilis , dan Hepatitis, penyakit tersebut termasuk kategori penyakit yang ada dalam pemeriksaan triple eliminasi yang merupakan penyebab kematian pada ibu. Laporan terbaru United Nations Programme on HIV and AIDS (UNAIDS) menunjukkan jumlah orang dengan HIV meningkat di 50 negara, termasuk Indonesia, 
dengan lebih dari 1,8 juta orang baru terinfeksi virus mematikan ini pada 2017. Yang lebih menyedihkan, 180 ribu anak (0-14 tahun) terinfeksi virus tersebut tahun lalu dan 110 ribu anak tewas karena penyakit yang terkait dengan AIDS. Jumlah kasus human immunodeficiency virus (HIV) di Indonesia periode Januari-Mei 2018 sebanyak 12.578 penderita, sedangkan kasus acquired immuno deficiency syndrome (AIDS) sebanyak 3.448 kasus (Pusdatin Kemenkes RI, 2018). Risiko penularan HIV dari ibu ke bayi terjadi pada kehamilan yakni 5-10 \% persalinan 10-15 \%, dan pascapersalinan 5-20 \% (De Cock dkk, 2000). Menurut data Pusdatin 2017, prevalensi infeksi HIV pada ibu hamil $0,3 \%$, sifilis $1,7 \%$, dan hepatitis $B$ $2,5 \%$ berturut-turut.

Pemerintah melakukan berbagai usaha untuk menurunkan AKI dan AKB dalam Pencegahan Penularan dari lbu ke Anak (PPIA) pemerintah melakukan kegiatan yang komprehensif, dengan meningkatkan pelayanan, pencegahan, terapi, dan perawatan, untuk ibu hamil dan bayinya, selama masa kehamilan, persalinan, dan sesudahnya. Intervensi yang dilakukan pada penularan HIV berupa: pelayanan kesehatan ibu dan anak yang komprehensif, layanan testing dan konseling, pemberian obat antiretrovirus (ARV), konseling tentang HIV dan makanan bayi, serta pemberian makanan bayi, dan persalinan yang aman. Intervensi untuk menurunkan penyakit HIV, Sifilis, Hepatitis B pemerintah membuat Peraturan Menteri Kesehatan Nomor 52 Tahun 2017 tentang 3E (Triple Eliminasi): pemeriksaan pada setiap ibu hamil terhadap HIV, sifilis, dan hepatitis B yang merupakan salah satu bukti komitmen negara Indonesia terhadap masalah ini dengan tujuan penurunan angka infeksi baru pada bayi baru lahir sehingga terjadi pemutusan mata rantai penularan dari ibu ke anak.

\section{METODE PENELITIAN}

Desain penelitian yang digunakan adalah deskriptif analitik. Tempat penelitian JI. Cempaka Raya No.10 Cempaka Putih, Jakarta Pusat dengan waktu penelitian bulan April Mei 2019. Sampel penelitian berjumlah 40 responden dengan menggunakan teknik accidental sampling. Penelitian ini menggunakan data primer yang diperoleh langsung dari responden dengan menggunakan instrumen kuisioner yang berjumlah 25 soal. Pengolahan data melalui tahap editing, coding, tabulating dan analisis data.

\section{HASIL DAN PEMBAHASAN}

Hasil penelitian pada 40 ibu hamil di PMB Suciati Cempaka Putih Jakarta Pusat nulan April-Mei 2019 diperoleh hasil bahwa sebanyak $82 \%$ responden) berpengetahuan kurang dan yang mempunyai pengetahuan baik sebanyak 3\% (1 responden). Hal ini sesuai dengan pendapat 
Notoatmodjo (2012) bahwa pengetahuan adalah hasil tahu dari manusia yang sekadar menjawab pertanyaan contohnya tentang triple Eliminasi, hal ini dapat dilihat bahwa sebagian besar ibu hamil belum mendapatkan informasi yang cukup tentang pemeriksaan triple eliminasi yang diperoleh dari tenaga kesehatan, media cetak dan media elektronik.

\section{Tabel 1. Tabel Hasil Pengukura} Responden Tentang Pemeriksaan Triple Eliminasi

\begin{tabular}{llll}
\hline Karakteristik & Hasil Ukur & Jumlah & $\begin{array}{l}\text { Persentas } \\
\text { e (\%) }\end{array}$ \\
\hline Pengetahua & Kurang & 33 & 82 \\
$\mathrm{n}$ & Cukup & 6 & 15 \\
Usia & Baik & 1 & 3 \\
\multirow{4}{*}{ Pendidikan } & 20-35 tahun & 34 & 85 \\
& D35 tahun & 6 & 15 \\
& Menar & 12 & 30 \\
& Perguruan & 14 & 35 \\
Pekerjaan & Tinggi & & 35 \\
& Tidak bekerja & 20 & 50 \\
Paritas & Bekerja & 20 & 50 \\
& Primigravida & 17 & 43 \\
& Multigravida & 21 & 52 \\
& Grandemultipar & 2 & 5 \\
& a & & \\
Sumber & Nakes & 25 & 62 \\
Informasi & Elektronik & 10 & 25 \\
& Media massa & 5 & 13 \\
\hline
\end{tabular}

Sumber : Data Primer (2019) Penelitian ini didukung dengan penelitian Arniti yang menunjukkan bahwa ada hubungan antara pengetahuan ibu hamil dengan penerimaan tes HIV. Penelitian lain yang dilakukan oleh Lamarque (2012) juga menunjukkan bahwa pengetahuan tentang berbagai aspek HIVIAIDS adalah faktor yang ditemukan oleh peneliti bisa memainkan peran dalam keputusan untuk tes HIV .
Faktor yang mempengaruhi pengetahuan seseorang menurut Mubarak (2011) adalah umur, pendidikan, pekerjaan, paritas dan sumber informasi. Umur adalah usia seorang yang terhitung mulai saat dilahirkan sampai berulang tahun. Semakin cukup umur, tingkat kematangan dan kekuatan seseorang akan lebih matang dalam berfikir dan berkerja. Umur mempengaruhi daya tangkap dan pola pikir seseorang. Semakin bertambah usia akan semakin berkembang pula daya tangkap dan pola pikirnya sehingga pengetahuan yang dia peroleh semakin membaik. Hurlock (2012) menyatakan bahwa usia 20-35 tahun disebut masa dewasa dimana pada masa ini diharapkan masalah-masalah yang dihadapi dengan tenang secara emosional, terutama dalam menghadapi kehamilan, persalinan dan merawat bayi. Pada masa ini seseorang akan lebih perperan aktif dalam masyarakat dan sosial. Selain itu juga akan lebih banyak menggunakan banyak waktunya untuk membaca. Kemampuan intelektual, pemecahan masalah dan kemampuan verbal dilaporkan hampir tidak ada penurunan pada usia ini.

Tingkat pengetahuan ibu hamil yang baik dipengaruhi oleh faktor umur responden mayoritas berusia 20-35 tahu yaitu $80 \% \quad(28$ responden). Menurut Hurlock (2012) semakin cukup umur, tingkat berfikir sesorang lebih matang dan dewasa. Hal ini di dukung oleh penelitian 
Othman (2015) yang menunjukkan adanya hubungan yang signifikan antara pengetahuan tentang HIVIAIDS dengan usia yang lebih matang dengan $p$ value $=0.005$. Pendidikan adalah suatu bimbingan yang diberikan seseorang kepada orang lain agar dapat memahami sesuatu hal. Pendidikan sebagai pengembangan kepribadian dan kemampuan didalam maupun diluar sekolah dan berlansung seumur hidup. Pendidikan sangat berpengaruh dengan proses belajar seseorang, semakin tinggi pendidikan seseorang semakin mudah pula orang tersebut memperoleh informasi. Baik dari orang lain maupun media masa. Semakin banyak informasi tentang kesehatan yang diperoleh maka semakin banyak pula pengetahuan yang didapat. Pengetahuan yang baik sangat mempengaruhi pola pikir seseorang, karena semakin tinggi pengetahuan seseorang semakin tinggi pula kemampuan dan kesadaran mereka dalam menerima informasi. Tingkat pengetahuan ibu hamil yang baik dipengaruhi oleh faktor pendidikan responden yang mayoritas berpendidikan tinggi atau minimal SMA/Sederajat 85,7\% (30 responden). Hal tersebut sesuai dengan Permendiknas yang menyataan bahwa dikatakan pendidikan tinggi jika pendidikan lebih dari 9 tahun (minimal tamat SMA/Sederajat).

Mubarak (2011) bahwa tingkat pendidikan ikut menentukan mudah atau tidaknya seseorang menyerap dan memahami pengetahuan yang mereka peroleh, karena pada umumnya semakin tinggi pendidikan seseorang maka semakin mudah penerimaan informasi. Hal ini didukung oleh hasil penelitian Anggraini (2014) yang menyimpulkan adanya hubungan antara tingkat pendidikan dengan pengetahuan tentang HIVIAIDS. Semakin tinggi pendidikan seseorang maka semakin baik pengetahuan tentang HIVIAIDS.

Pekerjaan merupakan kegiatan yang dilakukan sehari-hari untuk mendapatkan upah guna memenuhi kebutuhan hidup. Menurut Mubarak (2011) Lingkungan pekerjaan dapat membuat seseorang memperoleh pengalaman dan pengetahuan, baik secara langsung maupun tidak langsung. Karakteristik pekerjaan responden yang bekerja 50\% (20 responden) dan yang tidak bekerja $50 \%$ (20 responden).

Notoatmodjo (2010) bahwa seseorang yang mempunyai sumber informasi yang banyak akan mempunyai pengetahuan yang luas. Dikaitkan dengan pengetahuan responden yang tidak bekerja dapat diasumsikan masih kurang untuk mendapatkan informasi, namun adanya program VCT atau PITC bagi ibu hamil petugas kesehatan dapat menyalurkan informasi yang baik kepada ibu hamil. Selain dari petugas kesehatan ibu hamil mendapatkan informasi dari media sosial.

Lingkungan merupakan segala sesuatu yang ada disekitar individu, 
baik lingkungan fisik, biologis, maupun sosial. Lingkungan berpengaruh terhadap proses masuknya pengetahuan kedalam individu yang berada dalam lingkungan tersebut. Hal ini terjadi karena ada interaksi timbal balik ataupun tidak, yang akan direspon sebagai pengetahuan oleh setiap individu. Hal ini sangat berkaitan erat pengetahuan responden dengan pemeriksaan triple eliminasi yaitu petugas membuat lingkungan yang menghadirkan stimulasi yang merangsang responden untuk lebih memahami tentang pemeriksaan triple eliminasi yaitu dengan menawarkan informasi dan tes terkait pemeriksaan triple eliminasi yang dilakukan oleh petugas kesehatan. Informasi yang diperoleh melalui kenyataan (melihat dan mendengar sendiri), melalui media sosial, surat kabar, radio, televisi sehingga dapat menambah informasi. Hal ini sesuai dengan teori L.Green bahwa teketersediaan dan keterjangkauan merupakan faktor yang memungkinkan sesuatu motivasi dapat dilaksanakan.

\section{DAFTAR PUSTAKA}

Dinas Kesehatan Provinsi DKI Jakarta. Profil Profil Kesehatan DKI Jakarta.2016.

Direktorat Jenderal Pencegahan dan Pengendalian Penyakit kementerian Kesehatan 2017 Pedoman Eiminasi penularan HIV, Sifilis dan Hepatitis B dari Ibu ke Anak.
Direktorat Jenderal Pengendalian Penyakit Dan Penyehatan Lingkungan Kementerian Kesehatan Republik Indonesia.

Geraminejad P, Memar O, Aronson I, Rady PI, Hengge U, Tyring SK. Kaposi's sarcoma and Other Manifestations of Human Herpesvirus 8. J Am Acad Dermatol 2002; 47:641-55.

Hurlock, E. B. (2012). Psikologi Perkembangan, Suatu Pendekatan Rentang (terjemahan).

Sepanjang Kehidupan Erlangga.

Kementerian Kesehatan Republik Indonesia. Survey Demografi Kesehatan Indonesia (SDKI). Jakarta : 2016.

Kementerian Kesehatan Republik Indonesia.2017. Peraturan Menteri Kesehatan Republik Indonesia Nomor 52 Tahun 2017 Tentang Eliminasi Penularan Human Immunodeficiency Virus, Sifilis, Dan Hepatitis B Dari Ibu Ke Anak. Jakarta : Kemenkes RI.

Lamarque, KJ, "HIV Testing of Pregnant Women in the Fort Dauphin Region of Madagascar", 2013, Madagascar: Stellenbosch University. Diakses di https://scholar.sun.ac.za/bitstre am/handle/10019.1/79898/lam arque_hiv_2013.p df

Mubarak. W. I. (2011). Promosi kesehatan. Jogyakarta : Graha ilmu. 
Ni Ketut Arniti, Lila Wulandari,. Wirawan Faktor-Faktor yang Berhubungan dengan Penerimaan Tes HIV oleh lbu Hamil di Puskesmas Kota Denpasar. Public Health and Preventive Medicine Archive Juli 2014 Vol 2.

Notoatmodjo, S. 2010. Metodologi Penelitian Kesehatan. Jakarta : Rineka Cipta.

Othman, K. and A.H. Baharuddin. 2015. The total factor productivity in strategic food crops industry of Malaysia. Asian Journal of Agriculture and Rural Development. 5 (5): 124 - 136.

Peraturan Menteri Kesehatan Republik Indonesia Nomor 52
Tahun 2017 tentang Eliminasi Penularan Human Immunodeficiency Virus, Sifilis dan Hepatitis B dari lbu ke Anak.

Petunjuk Teknis Tata Laksana Klinis Ko-Infeksi TB-HIV. Jakarta: Kementerian Kesehatan RI; 2012.

Thomas S, Java A. HIV-associated Kaposi's sarcoma. Hospital Physician. 2000; 36: 22-32. 8. Wolff K, Goldsmith LA, Katz SI, Gilchrest BA, Paller AS, Leffell DJ. Fitzpatrick's dermatology in general medicine. 8th edition. New York: McGraw-Hill Companies; 2012. p.1481-8. 